Elsevier Editorial System(tm) for Public Health

Manuscript Draft

'Freedom and the State: Nanny or Nightwatchman?', Public Health, Vol 30, 2015, 1-6

Manuscript Number: PUHE-D-14-00622R1

Title: Freedom and the State: Nanny or Nightwatchman?

Article Type: Review Article

Keywords:

Corresponding Author: Prof. Philip Pettit,

Corresponding Author's Institution: Princeton University

First Author: Pettit Philip

Order of Authors: Pettit Philip

Abstract: There are two rival images often offered of the state. In one the state serves like a nanny to provide for the welfare of its members; in the other it requires people to look after themselves, providing only the service of a night-watchman. But this dichotomy, which is routinely invoked in debates about public health and welfare provision in general, is misleading. What the rival images turn on is not competing pictures of how the state should function in people's lives but competing pictures of what it is to guard the freedom of its people. On the neo-liberal theory, which has been dominant over the last century or so, providing for people's freedom means leaving them to their own devices and fortunes. On the neo-republican theory, which answers to a much longer tradition, it means democratically identifying a common set of basic liberties in the exercise of which everyone should be protected by law and, if necessary, resourced. This older way of thinking about freedom has important merits missing in the newer and argues strongly against the night-watchman state. 
09 September 2014

Public Health Editorial Office

The Royal Society for Public Health

John Snow House

59 Mansell Street

London

E1 8AN

Tel: +44 (0)20 31771632

Fax: +44 (0)20 31771601

To The Editors

\section{Re: Freedom and the State: Nanny or Nightwatchman?}

Please find enclosed the above manuscript, which I hope you will consider for publication in Public Health.

This manuscript discusses one of the main issues of public health, and of other public goods bears on how far the state should cater for the needs of individuals and how far it should encourage individuals to cater for their own needs. This manuscript contributes fresh insights into the history of rival ways of thinking about freedom and principles of government impacting population health.

This paper was written with the readership of your journal as the intended audience. The manuscript reports original research that has not been previously published and has not been submitted to any other journal for consideration.

I look forward to the opportunity to have this manuscript reviewed in your journal's peer review process. Please contact me on either 609.258.4759 or ppettit@ princeton.edu if you require additional information. I look forward to receiving notice of your decision.

Yours sincerely,

Philip Pettit

Laurence S. Rockefeller University Professor of Politics and Human Values 


\section{Freedom and the State: Nanny or Nightwatchman?}

Philip Pettit ${ }^{1}$

Highlights

- One of the main issues in discussions of public health, and of other public goods, bears on how far the state should cater for the needs of individuals and how far it should encourage individuals to cater for their own needs.

- On the one side are those who argue for a nanny state.

- On the other are those who argue for a state that serves like a nightwatchman to guard against only limited dangers, letting people generally look after their own welfare.

- The conflict between these two views of the law and the state is often represented as a conflict between those who care primarily about the welfare of people, whether that is secured by people themselves or by their government, and those who care mainly about people's freedom and autonomy.

- A philosophically more challenging, and historically more enlightening, account would trace the divide to two different images of what freedom involves.

\footnotetext{
${ }^{1}$ University Center for Human Values, Princeton University, Princeton, NJ 08544; and School of Philosophy, Australian National University, Canberra, ACT 0200.
} 


\section{Freedom and the State: Nanny or Nightwatchman?}

Philip Pettit*

One of the main issues in discussions of public health, and of other public goods, bears on how far the state should cater for the needs of individuals and how far it should encourage individuals to cater for their own needs. On the one side are those who argue, as their opponents put it, for a caring, paternalistic - better perhaps, maternalistic - nanny state. On the other are those who argue, again in the words of opponents, for a state that serves like a nightwatchman to guard against only limited dangers, letting people generally look after their own welfare.

Proponents of the nanny state will tend to support restrictions on how far companies should be allowed to expose people to dangers like those associated with smoking and temptations like those associated with sugary drinks. Proponents of the nightwatchman state will tend to oppose such restrictions on the grounds that the state should not make decisions for its citizens as to what they consume; indeed it should not even make decisions for its children but rather leave the relevant issues to be decided by the children's parents.

The conflict between these two views of the law and the state is often represented as a conflict between those who care primarily about the welfare of people, whether that is secured by people themselves or by their government, and those who care mainly about people's freedom and autonomy. I think that this representation is misleading insofar as it suggests that those on the side of the nanny state have to be hostile to the idea of letting people make their own decisions and shape their own lives.

A philosophically more challenging, and historically more enlightening, account would trace the divide to two different images of what freedom involves. Those who lobby for the nightwatchman image of the state generally adopt what I think of as broadly a neo-liberal view of freedom. Rather than invoking a different value from

\footnotetext{
* University Center for Human Values, Princeton University, Princeton, NJ 08544; and School of Philosophy, Australian National University, Canberra, ACT 0200.
} 
freedom - say, the value of welfare - their opponents ought to argue instead that there is a rival, more anciently rooted way of thinking about freedom - a neorepublican conception, as I call it - that supports their insistence that the law and the state should go beyond a nightwatchman role. ${ }^{1}$

In this short paper I sketch a history of these rival ways of thinking about freedom and then I use that history to reconstruct the competing principles of government that they would support. This reconstruction gives us an image of neo-republican theory, on the one side, neo-liberal theory on the other, as philosophies for the conduct of domestic government. And with those two images clearly in view, I return in a brief conclusion to the issue between the rival visions of the state.

\section{The history of neo-republican freedom}

The older view of freedom goes back to republican, Roman days, and to the enormously influential writings of figures like Polybius, Cicero and Livy. On this way of thinking, which was to survive for two millennia, to be free meant to be a free person. And to be a free person in turn meant that you did not have to live under the will of a master; and that this wasn't just a matter of good luck: you were adequately resourced and protected against being controlled by a master's will.

How, according to Roman thinking, did you get to be a free person in this sense? The general assumption was that all citizens - in effect, all non-enslaved, native men could expect to be equally free, at least in the ideal. And so the idea was that the citizens of a society would be free insofar as two conditions were satisfied. First, the law defines a range of choices - later, to be called the basic or fundamental liberties - where they are individually able to act as they wish, without being subject to the private will of another. And second, the law that guards them in this way does not itself represent the imposition of a public will by a monarch or an aristocracy or a colonial power: it is framed on terms that the citizens collectively impose on their government.

This conception of what it is to enjoy freedom meant that there are two ways in which you might be un-free. One, by being subject to the private will of another, as 
in being the slave of a master or a woman subject to her husband's will. Two, by living under a law that is imposed at the will of a particular person or party, not under a law that, together with other citizens, you have a part in shaping. The Latin word for subjection to the will of another - subjection to a master or dominus was dominatio, which we may translate as 'domination'.2 And so the idea was that freedom requires the absence both of private and of public domination.

One of the striking themes in this Roman conception of freedom was the insistence that if you are subject to someone else's domination - if their will is paramount in the area, roughly, of your basic liberties - then that makes you un-free, even if the master in your life is entirely good-willed and inclined to let you choose in that area according to your own wishes. Thus Roman comedies made fun of the figure of the slave who thought he was free because his master was gentle or gullible or just often away. ${ }^{3}$ And those who later followed the Roman, republican way of thinking always maintained that to live under a law that was subject even to a wholly benevolent despot was to live in un-freedom; in order to live in freedom the law had to be a public affair - a res publica - not something in the control of any private or foreign power.

This way of thinking about freedom identified it, therefore, with the enjoyment of both private and public non-domination. Although it continued to command lipservice, freedom as non-domination ceased to have much relevance in Rome after the rise of the Empire at the beginning of the common era. But it regained a powerful presence in public life with the rise of the city-states of northern Italy Venice, Florence, Siena, Perugia and the like - a thousand years later, in the high middle ages.

The burghers of these new trading centers had generally thrown off the control of local lords by the late twelfth century and began at the point to cast themselves as citizens in the Roman mould. They insisted that living under a law that was of their own collective making, and being each protected in an individual sphere of choice by that law - being secured in their basic liberties - they enjoyed exactly the sort of freedom that the Romans cherished. And since their trading centers became the 
great centers of learning in the Renaissance period, they bequeathed this neoRoman way of thinking about freedom to the northern European countries in the 1500 's and 1600's.

The legacy of republican thinking that these northern countries inherited led in many cases to constitutional upheavals. It shaped the republic of the nobles in Poland, it inspired the Dutch republic that was formed after the expulsion of the Spanish, and it fuelled the revolution that led to the English republic of the 1640's and 1650's. Thomas Hobbes, an opponent of the English revolution, railed at this 'false show of liberty', remarking famously that 'there was never anything so dearly bought as these western parts have bought the learning of the Greek and Latin tongues'. ${ }^{4}$

The republican conception of freedom that inspired these upheavals remained in common currency in the English-speaking world, even after the restoration of Charles II in 1660. Indeed, with the introduction of a broadly constitutional monarchy after 1688 - a monarchy that was no longer seen as necessarily inimical to republican freedom - it achieved the status of an orthodox ideal in most strains of political thinking. Freedom in this sense consists in 'independency upon the will of another', as Algernon Sidney put it in the 1680 's. ${ }^{5}$ Or as the idea was formulated in Cato's Letters, a radical tract of the 1700 's, 'Liberty is, to live upon one's own terms; slavery is, to live at the mere mercy of another' ${ }^{6}$

In this way of thinking, true to its Roman origins, you were un-free even if your master or lord was entirely good-willed. As Sidney wrote, 'he is a slave who serves the best and gentlest man in the world, as well as he who serves the worst'. ${ }^{7}$ And that message was taken, not just to rule against the private domination of a gentle individual master, but also against the public domination of a gentle colonial master. Writing in the 1770's, the radical clergyman and mathematician, Richard Price, emphasized the point forcefully. 'Individuals in private life, while held under the power of masters, cannot be denominated free, however equitably and kindly they may be treated. This is strictly true of communities as well as of individuals' ${ }^{8}$ 
The republican conception of freedom as non-domination reached perhaps the greatest height of influence about the time of the American war of independence. One of the things that had really upset the American colonists is that in 1766 when the Westminster Parliament had been persuaded to withdraw the tax imposed by the Stamp Act, it went out of its way to claim that, although choosing to exercise indulgence, it enjoyed as 'of right' the 'full power and authority to make laws and statutes' binding the Americans. This was just to say that it claimed the position of a master, albeit a kindly master. And if that claim was admitted then, by the received ideal, the American colonists could not count as free. Despite the existence of literal slaves in the American lands, this led to a general complaint among the colonists, in the words of a 1772 resolution in Boston, that 'we are degraded from the rank of Free Subjects to the despicable Condition of Slaves' ${ }^{9}$

And now we confront one of the great ironies in the history of political thought. At just the time when the republican conception of freedom attained its greatest influence, sparking a successful war of independence in the American colonies, an alternative conception made an appearance and quickly gained currency, even dominance. This is the conception that came to be identified as classical liberal in character and that we today would naturally describe as neo-liberal or liberatarian.

The history of neo-liberal freedom

In 1776, Richard Lind, a pamphleteer writing on behalf of the British Prime Minister, Lord North, first introduced the new idea of freedom. Freedom is 'nothing more or less than the absence of coercion', he said, ascribing this idea, wholly inimical to received ideas, to 'a very worthy and ingenious friend'. But that means, he then pointed out, that since 'all laws are coercive', the laws themselves take from people's liberty, even if they do so in the hope of reducing the overall level of coercion. And if that is the case, he asked, what is the complaint of the Americans? They are ruled by law, to be sure, but so are those in mainland Britain and so indeed are those in any society whatsoever. ${ }^{10}$ 
Where the earlier view had depicted freedom as the product of a protective, popularly controlled law, this view makes law into the antonym of freedom: a form of coercion, whether of body or will, that reduces the choices available to subjects. This is indeed a new view, as the worthy friend had claimed in a letter to Lind. The friend was Jeremy Bentham and in that letter he reported 'a kind of discovery I had made, that the idea of liberty...was merely a negative one', and should be defined as 'the absence of restraint'.11 Bentham's view of freedom may have appeared briefly in Hobbes, whether or not he was aware of the fact, but he gave it a sharper definition and a greater importance, making it into 'the cornerstone of my system', as he put it in the letter.

This novel view of freedom was useful for Lind and others in rejecting the republican argument against colonialism, even the supposedly gentle colonialism of Westminster in relation to the American colonists. But it probably survived because it also served other purposes in the thinking of Bentham and his utilitarian associates, and in the thinking of a new movement that came to be known as classical liberalism.

Bentham himself was a reformer, committed broadly to an inclusive view of the citizenry, and the new view of freedom was useful in allowing him to argue that the law should cater for the equal freedom of all, without seeming to call for a complete overturning of the status quo. To have called for the equal non-domination of all, women and workers included, would have been utterly radical, requiring the transformation of existing family and master-servant law. But to call for equal noncoercion or non-interference was not at all so revolutionary. It was possible that a wife or worker could be as free in this sense as the master, notwithstanding their subjection to his will, provided that the master stayed his hand and did not actually impose interference.

One prominent utilitarian of the time was William Paley, who exercised a great influence over moral and religious thinking in nineteenth century Britain. He adopted the new view of freedom in a book published in 1785 that became a required part of the Cambridge syllabus and remained so down to 1925. In making 
the case for what he cast as a novel view - it jars, he admitted, with 'the usage of common discourse' - he acknowledged that nothing more than freedom in this new, downgraded sense could be established for all. Thus he contrasted it with those accounts of freedom, such as the republican, 'which, by making that essential to civil freedom which is unattainable in experience, inflame expectations that can never be gratified, and disturb the public content with complaints, which no wisdom or benevolence of government can remove'.12

The new conception of freedom as non-interference or non-coercion may have appealed to the likes of Bentham and Paley for making it possible to be relatively egalitarian without being utterly radical. But it appealed to classical liberals for the fact that it provided a way of justifying the new legal and political order that industrialization was calling into existence. In this new order, great numbers of people moved off the land and, with growing industrialization, scrambled for subsistence jobs in the mines, mills and factories, in various cottage industries, and in the construction of the canals and railways. The conditions of most workers were appalling, even by standards current at the time, and a question that naturally arose was whether the people who endured such conditions could count as free.

The new way of thinking suggested that they could. They may have been subjected to their new masters in the manner of 'wage slaves', as many adherents of the older republican way of thinking insisted..$^{13}$ And they may have been forced by fear of death or destitution to accept the conditions of industrial labor. But they were not strictly coerced - they were not gang-pressed or threatened - into submission. They made an un-coerced decision to work on the terms their employers offered, even if they had little option but to accept those terms. They enjoyed what was celebrated by classical liberals as freedom of contract: freedom to decide on who to work for, on what terms, and under what conditions.

The republican notion of freedom had focused on the freedom of each person, and on the requirements it put in place for reducing any private or public domination. The newer notion shifted the focus to choice, suggesting that the free society is one where relations are organized, so far as possible, on the basis of negotiation, 
contract and consent. No matter that such a society is likely to display great inequality, to impose conditions on many where their choices are driven by fear and need, and to give some the position of masters in relation to others. It still answers broadly to classical liberal requirements. It satisfies the mantra, for example, that Robert Nozick formulated in defending a version of the appraoch: 'From each as they choose, to each as they are chosen'. ${ }^{14}$

With the shift to a focus on the free choice rather than the free person, the new theory of freedom moved concern away from domination, whether private or public in character. It did not matter in this view that you lived under the private domination of a master, provided the master dealt with you contractually and did not impose any actual coercion. And it did not matter in this view that you lived under the public domination of government. The coercion of government is acceptable, however undemocratic, to the extent that it restricts private coercion, facilitates contract and choice, and is kept to the minimal level required for those purposes. Thus William Paley argued that if it operated in this pattern 'an absolute form of government' would be 'no less free than the purest democracy'. ${ }^{15}$

The shift of focus from person to choice had enormous ramifications for how to conceive of the relation between government or law on the one hand and the freedom of individuals on the other. In the older conception it was government and law that made freedom possible and accessible for citizens. In the newer it was the contractual free-for-all of the market that made freedom possible. To the extent that government and law went beyond the maintenance of market conditions, then, it took away from people's freedom rather than enhancing it. In this new vision, as Ronald Regan put it two hundred years later, government is the problem, not the solution.

Neo-republicanism and neo-liberalism

What would these two ideals of liberty support as principles for the conduct of government in a contemporary society? I assume that each approach would be 
inclusive in recognizing as full citizens all the adult, able-minded, more or less permanent residents of the society. I say nothing on how far it should be ready to accept would-be immigrants and refugees into the ranks of the citizenry. ${ }^{16}$ And equally I say nothing on how it would argue for the treatment of children or of those who are not able-minded. Those issues are beyond my brief.

There are two aspects under which any philosophy of government will dictate principles for the organization of society and they can be cast roughly as social justice, on the one side, and democratic justice on the other. A society will be socially just to the extent that it organizes relations between individuals and the corporate bodies that individuals constitute in a way that treats all citizens as equals. And a society will be democratically just to the extent that it organizes relations between citizens and the government that rules over them in a way that treats them as equals. Every philosophy of government gives its own account of what it is for citizens to enjoy treatment as equals and each applies that account to the horizontal relations of people to one another - the subject of social justice - and to their vertical relations to their government: the subject of democratic justice.

The principles of a neo-republican philosophy of government are readily formulated, in light of our brief history of the ideal it sponsored.

1. Social Justice:

The law should identify a common set of basic liberties and enable each to exercise those liberties without private domination by others.

2. Democratic Justice:

This law should be framed and implemented by government under a form of popular control that guards against public domination.

What are these principles going to support in practice? The principle of social justice is obviously going to require institutions, supported under law, that provide each citizen with a range of security: basic security against aggression, of course, but also educational security, social security, medical security, judicial security, workplace security and the shared securities associated with provisions for food reliability, public health, environmental sustainability, and indeed the defense of the country. 
How far should the state secure people in these and other areas? An established republican theme can be of help here. This is the age-old association between being a free, un-dominated person and being able to look others in the eye without reason for fear or deference. If the law can deliver a world that passes or comes close to passing this eyeball test of social justice, then it ought to appeal to the most demanding amongst us. That world may allow for material inequalities and it may have to restrict some individual securities for the sake of the system overall: for example, it may have to reduce workplace security in order to increase employment. But it will still deliver a palpable and palpably attractive ideal.

What does the neo-republican principle of democratic justice require? There is more to be said in this context than is possible here but it should suffice to point out some of the more obvious preconditions: an electoral system in which each has an equal part; a parliamentary system in which the executive is held properly to account; a strict separation of judicial from other power; a system in which decisions where elected officials have a special interest are put at arm's length from parliament; a campaign system in which politicians do not have to put themselves in the debt of the wealthy; a balanced media that operates under a guarantee of freedom of information; a lobby system in which the grounds and modes of pressure exerted upon government are forced into the public eye; a system of contestation, formal and otherwise, in which all may play an uninhibited part; and a network of publicinterest, watchdog bodies that can keep government on its toes.

And now consider the corresponding principles that a neo-liberal philosophy would support.

1. Social Justice:

The law should establish a market that facilitates contract and choice, imposing the minimal system of coercive protection that this requires.

2. Democratic Justice:

This law should be controlled in such a way - presumptively, in such a democratic way - that people's contractual freedom is maximized . 
These principles point in a very different direction from their neo-republican counterparts. The principle of social justice would support a minimal state apparatus for ensuring law and order and within that framework it would argue for letting the market go where it will, even should this lead to extreme inequality, great imbalances of power, and multiple sites of domination. What remedies should apply in cases where the market does not lift the destitute or dependent out of their penury? The answer often proposed is: the remedies to be provided by the private philanthropy of the rich. Even if it fosters domination, as the haves lord it over the have-nots, philanthropy will ensure the satisfaction of Nozick's principle: from each as they choose, to each as they are chosen.

Where does the neo-liberal principle of democratic justice point? As Paley already noticed, and as those advocating China's neo-liberal reforms are well aware, it does not strictly require democracy. All that it requires is that system, whatever it is, that most reliably delivers the market-centred vision of social justice. In his "Essay on Man", Alexander Pope may best articulate the bottom line: 'For Forms of Government let fools contest. Whatever is best administered is best'. To be fair, many neo-liberals strongly believe that democracy is likely to be essential for the wellordered market society that they cherish. But the linkage that they make to democracy is still much weaker than in the alternative picture and, apart from supporting the independence of the judiciary, it offers little in the way of specifications for how democracy itself should be ordered.

Back to the issue

Once we put up the two ideals of freedom, neo-liberal and neo-republican, and once we identify the rival philosophies of government that they describe, we gain a good vantage point for considering whether the state ought to assume the profile of a nanny or a nightwatchman.

The neo-republican view argues for allowing the state to do a great deal in establishing a framework within which people can make their own lives, carving out the areas where they can enjoy personal sovereignty. The framework it supports 
might certainly restrict initiatives on the part of some that would put public health or any other public good at risk; for example, it might well argue for imposing serious regulations and restrictions on the food industry. But it would not do this in the cause of molly-coddling people who are presumed to be unable to look after themselves. And so it would not fall foul of the usual rhetoric and criticism that is deployed by neo-liberals.

The neo-republican view would argue that a relatively interventionist framework is an essential part of the infrastructure of people's freedom: that is, their freedom as un-dominated citizens, competent and secure in the exercise the basic liberties protected by law. Moreover, it would support that framework only insofar as the arrangement passed democratic muster, attracting electoral support and surviving the interrogation of various public-interest bodies - for example, various consumer groups - in an active civil society.

It is important to be able to make the case for such state interventions on the basis of the ideal of freedom. With the language of freedom figuring on both sides of the debate between the two visions of the state, it becomes possible to make a fair assessment of the two philosophies. The issue is no longer one of whether we challenge people, as neo-liberals would put it, or condescend to them. The issue is between rival ideals of freedom. Should we be primarily concerned with people's enjoying the status of equal, un-dominated individuals in their relations with one another? Or should we strive for a society that allows maximally unrestricted choice, whatever the consequences for people's relative standing: for example, whatever the consequences for the relations of domination between them? I do not pretend to be able to resolve that question in the short compass of this paper. But I imagine it is clear where my own sympathies lie. And I would like to think that it is clear where the sympathies of detached observers ought to take them.

\footnotetext{
${ }^{1}$ For an elaboration of this rival view of freedom see Pettit, P. (1997). Republicanism: A Theory of Freedom and Government. Oxford, Oxford University Press; Skinner, Q. (1998).
} 
Liberty Before Liberalism. Cambridge, Cambridge University Press; Pettit, P. (2014). Just Freedom: A Moral Compass for a Complex World. New York, W.W.Norton and Co.

2 On this notion see the appendix in Lovett, F. (2010). A General Theory of Domination and Justice. Oxford, Oxford University Press.

${ }^{3}$ See Skinner Liberty before Liberalism, in his discussion of the figure of Tranio in Plautus's play, Mostellaria.

${ }^{4}$ Hobbes, T. (1994). Leviathan. ed E.Curley. Indianapolis, Hackett, Ch 21.

5 Sidney, A. (1990). Discourses Concerning Government. Indianapolis, Liberty Classics, 17.

6 Trenchard, J. and T. Gordon (1971). Cato's Letters. New York, Da Capo, Vol 2, 249-50.

7 Discourses Concerning Government, 441.

8 Price, R. (1991). Political Writings. Cambridge, Cambridge University Press, 77-78.

${ }^{9}$ Reid, J. P. (1988). The Concept of Liberty in the Age of the American Revolution. Chicago, Chicago University Press, 92.

10 Lind, J. (1776). Three Letters to Dr Price. London, T. Payne, 24 and 17.

${ }^{11}$ Long, D. C. (1977). Bentham on Liberty. Toronto, University of Toronto Press, 54.

12 Paley, W. (1825). The Principles of Moral and Political Philosophy, Vol 4, Collected Works. London, C. and J. Rivington, 357 and 359.

13 Sandel, M. (1996). Democracy's Discontent: America in Search of a Public Philosophy. Cambridge, Mass., Harvard Universty Press, 172-74.

14 Nozick, R. (1974). Anarchy, State, and Utopia. Oxford, Blackwell, 160.

15 Paley The Principles of Moral and Political Philosophy 166.

16 See Pettit \ust Freedom for a more comprehensive overview of the dictates of neorepublican principles both in domestic and international contexts. 
${ }^{*}$ Response to Reviewers

Response to Reviewers$$
\text { (2) }
$$

(1)

